УДК 618.145-007.61-02:616.9-022.3-053.8

DOI 10.11603/24116-4944.2020.1.11484

\author{
${ }^{\odot A . ~ В . ~ Б о и ̆ ч у к, ~ Т . ~ В . ~ В е р е щ а г і н а, ~ В . ~ С . ~ Ш а д р і н а, ~ О . ~ І . ~ Х л і б о в с ь к а, ~ В . ~ І . ~ К о п т ю х ~}$ \\ Тернопільсъкий національний медичний університет ілені І. Я. Горбачевсъкозо \\ МОЗ України
}

\title{
РОЛЬ ІНФЕКЦІЙНИХ ЗБУДНИКІВ У ЖІНОК ДІТОРОДНОГО ВІКУ 3 ГІПЕРПЛАСТИЧНИМИ ПРОЦЕСАМИ ЕНДОМЕТРІЯ
}

\begin{abstract}
Мета дослідження - проаналізувати роль інфееційного патогену в розвитку гіперпластичних процесів матки порівняно зі здоровими жінками для формування груп ризику щодо виникнення гіперпластичних змін слизової оболонки матки.

Матеріали та методи. Було обстежено 90 пацієнток гінекологічного відділення КНП «Тернопільська міська комунальна лікарня № 2» 3 доброякісною гіперплазією ендометрія у репродуктивному віці впродовж 2017-2019 рр., підтвердженою гістологічним висновком після оперативної гістероскопії. Контрольній групі пацієнток-добровольців (30 жінок) забір матеріалу здійснювали за допомогою «Пайпель» біопсії з дослідженням евакуйованого матеріалу з порожнини матки. Всім пацієнткам проводили дослідження на наявність таких збудників, як Micoplasma hominis, Ureaplasma urealiticum, Chlamydia trachomatis, Herpex simplex virus I, II методом імуноферментного аналізу (IФA) (IgG, IgM); Gardnerella vaginalis, Trichomonas vaginalis в мазках із піхви та уретри за методикою полімеразної ланцюгової реакції, а також здійснювали виявлення папіломавірусу людини (ПВЛ) 16 і 18 типів за допомогою методу полімеразної ланцюгової реакції.
\end{abstract}

Результати дослідження та їх обговорення. Найбільшого розповсюдження серед інфекційних агентів набув вірус папіломи людини 16 і 18 типів, який у дослідних групах був виявлений у 40,0 - 41,67 \% порівняно 3 контрольною групою - у 10,0 \%. Отримані дані зумовлюють необхідність проведення якісного інфекційного скринінгу для фрормування груп ризику щодо виникнення гіперпластичних змін слизової оболонки матки.

Висновки. Інфекційні агенти відіграють важливу роль у розвитку гіперпластичних змін слизової оболонки матки. Отримані результати дозволяють розглядати інфекційні патогени як кофактори гіперпластичних процесів матки, що патогенетично пов'язані з представниками фрлори нижніх відділів генітального тракту і беруть участь у реалізації запального процесу.

Ключові слова: гіперпластичні процеси ендометрія; інфекційний патоген; вірус папіломи людини 16 і 18 типів.

РОЛЬ ИНФЕКЦИОННЫХ ВОЗБУДИТЕЛЕЙ У ЖЕНЩИН ДЕТОРОДНОГО ВОЗРАСТА С ГИПЕРПЛАСТИЧЕСКИМИ ПРОЦЕССАМИ ЭНДОМЕТРИЯ

Цель исследования - проанализировать роль инфекционного патогена в развитии гиперпластических процессов матки по сравнению со здоровыми женщинами для формирования групп риска возникновения гиперпластических изменений слизистой оболочки матки.

Материалы и методы. Нами было обследовано 90 пациенток гинекологического отделения КНС «Тернопольская городская коммунальная больница № 2» с доброкачественной гиперплазией эндометрия в репродуктивном возрасте в течение 2017-2019 гг., подтвержденной гистологическим заключением после оперативной гистероскопии. Контрольной группе пациенток-добровольцев (30 женщин) забор материала осуществлялся с помощью «Пайпель» биопсии с исследованием эвакуированного материала из полости матки. Всем пациенткам проводилось исследование на наличие таких возбудителей, как Micoplasma hominis, Ureaplasma urealiticum, Chlamydia trachomatis, Herpex simplex virus I, II методом иммунофрерментного анализа (ИФА) (IgG, IgM); Gardnerella vaginalis, Trichomonas vaginalis в мазках из влагалища и уретры по методике полимеразной цепной реакции, а также проводилось выявление папилломавируса человека (ПВл) 16 и 18 типов с помощью метода полимеразной цепной реакции.

Результаты исследования и их обсуждение. Наибольшее распространение среди иноекционных агентов приобрел вирус папилломы человека 16 и 18 типов, в опытных группах был обнаружен у 40,0 - 41,67 \% по сравнению с контрольной группой -у 10,0 \%. Полученные данные обусловливают необходимость проведения качественного инсрекционного скрининга для фрормирования групп риска возникновения гиперпластических изменений слизистой оболочки матки.

Выводы. Инфекционные агенты играют важную роль в развитии гиперпластических изменений слизистой оболочки матки. Полученные результаты позволяют рассматривать инфекционные патогены как кофакторы гиперпластических процессов матки, которые патогенетически связаны с представителями фрлоры нижних отделов генитального тракта и участвуют в реализации воспалительного процесса.

Ключевые слова: гиперпластические процессы эндометрия; инфекционный патоген; вирус папилломы человека 16 и 18 типов.

\section{THE ROLE OF INFECTIOUS PATHOGENS IN WOMEN OF CHILDHOOD AGE WITH HYPERPLASTIC ENDOMETRIAL} PROCESSES

The aim of the study - to analyze the role of an infectious pathogen in the development of uterine hyperplastic processes in comparison with healthy women to form risk groups for the occurrence of hyperplastic changes in the uterine mucosa.

Materials and Methods. We examined 90 patients of the gynecological department of Ternopil City Clinical Hospital No. 2 with benign endometrial hyperplasia of reproductive age during 2017-2019, confirmed by histological findings after surgical hysteroscopy. In a control group of volunteer patients (30 women), material was collected using a Pipel biopsy with examination of the evacuated material from the uterine cavity. All patients were tested for pathogens such as Mycoplasma hominis, Ureaplasma urealiticum, Chlamydia trachomatis, Herpex simplex virus I, II by enzyme-linked immunosorbent assay (ELISA) (IgG, IgM); Gardnerella vaginalis, 
Trichomonas vaginalis in smears from the vagina and urethra by the method of polymerase chain reaction, as well as the detection of human papilloma virus (PVL) 16/18 was performed using the method of polymerase chain reaction.

Results and Discussion. The most common among infectious agents was the human papilloma virus type 16/18, which in the experimental groups was detected in $40.0-41.67 \%$ compared with the control group of $10.0 \%$. The obtained data necessitate high-quality infectious screening for the formation of risk groups for the occurrence of hyperplastic changes in the uterine mucosa.

Conclusions. The role of infectious agents play an important role in the development of hyperplastic changes of the uterine mucosa. The obtained results allow us to consider infectious pathogens as cofactors of hyperplastic processes of the uterus, which are pathogenetically associated with the flora of the lower genital tract and are involved in the implementation of the inflammatory process.

Key words: endometrial hyperplastic processes; infectious pathogen; human papilloma virus type 16/18.

ВСтУП. Проблема гіперпластичних процесів ендометрія (ГПЕ) посідає одне з головних місцьу гінекологічній практиці і складає (за різними даними) від 17 до 59 \% всієї гінекологічної патології [1-3]. Інтерес до вдосконалення діагностики та лікування доброякісних гіперпроліферативних уражень матки є не лише необхідним і доцільним з позиції онкологічної настороженості, але й з огляду на часті рецидиви патологічних змін, порушення репродуктивної функції у цієї категорії жінок, розлади оваріально-менструального циклу та розвиток хронічної анемії $[4,5]$.

Все більшої популярності у науковій літературі набуває теорія про хронічне запалення матки, при якому відбувається спотворення реалізації дії естрогенів на ендометрій і пригнічення фрункціональної активності нейтрофрілів, що призводить до імунного дисбалансу [6-8]. I все ж таки, важливу роль мікробного фрактора у підтримці запального процесу в ендометрії неможливо недооцінити, що доводять численні дослідження про важливу роль персистентної інфекції у розвитку ГПЕ [9-13]. Персистенція мікроорганізмів в ендометрії, що належать до умовно-патогенної мікросрлори, призводить до розвитку автоімунної реакції за рахунок загальних антигенів із тканинними антигенами організму. Роль запалення в розвитку ГПЕ підтверджується успішним досвідом використання протизапальної терапії в комплексному лікуванні ГЕ [14-16]. Доцільність деталізації патогенетичних ланок ГПЕ зумовлена поліпшенням діагностики та можливістю застосування в комплексній терапії методів лікування, здатних впливати на функції різних компонентів імунної системи $з$ врахуванням інфекційного «початку».

3'явилося поняття «мікробом матки», і вже відомо, що здоровий ендометрій містить більше 200 мікробних представників, серед яких домінують Proteobacteria, Firmicutes u Bacteroidetes, при цьому Lactobacillus і Bacteroidetes переважають в ендометрії в абсолютної більшості невагітних жінок. Таким чином, концепція сучасних досліджень запальних процесів, очевидно, зосереджена на розумінні того, яким чином різні бактеріальні групи організму спонукають до розвитку захворювань чи підтримують здоровий стан макроорганізму [17-19].

Встановлено також спроможність цитомегаловірусу людини (ЦМВ) та вірусу Епштейна-Барр посилювати трансформацію клітин, інсрікованих ВПЛ [20-22]. Водночас досліджено, що значна частка інфекційних чинників, а саме: вірус Епштейна-Барр, середнього та високого онкогенних ризиків інфекції ВПЛ (з поширеністю 16 і 18 типів), вірус герпесу 1 та 2 типів та ЦМВ-інфекція призводять до хронічного запального процесу, найчастіше в поєднанні з бактеріальною фрлорою $[23,24]$.
Проводили також дослідження особливостей клінічного перебігу генітальної ПВІ у жінок за умов мікстінфекційного ураження збудниками інших урогенітальних інфекцій, зокрема: Chlamidia trachomatis, Mycoplasma hominis, Ureaplasma urealiticum, Gardnerella vaginalis, грибами роду Candida [25, 26]. Відповідно до результатів порівняльних досліджень, у групі жінок, інфрікованих ВПЛ (341 пацієнтка), супутні урогенітальні інсрекції діагностовано у 78,6 \% обстежених, в тому числі: одна супутня інсрекція - у 12,3 \%, дві супутні інсрекції - у 39,0 \% та три супутні інфекції - у 27,3 \%. Згідно з даними аналізу результатів проведених досліджень, зазначено, що у відповідних хворих жінок ризик розвитку продуктивних проявів ПВІ суттєво зростає $[8,10]$. Таким чином, роль сексуально-трансмісивних інфекцій в розвитку гіперпластичних процесів потребує наукової конкретизації, що обґрунтовує доцільність проведення досліджень у цьому напрямку.

МЕТА ДОСЛІДЖЕННЯ - проаналізувати роль інорекційного патогену в розвитку гіперпластичних процесів матки порівняно зі здоровими жінками для фрормування груп ризику щодо виникнення гіперпластичних змін слизової оболонки матки.

МАТЕРІАЛИ ТА МЕТОДИ. БУЛо обстежено 90 пацієнток гінекологічного відділення КНП «Тернопільська комунальна міська лікарня № 2», які звертались за медичною допомогою з приводу доброякісної гіперплазії ендометрія у репродуктивному віці впродовж 2017-2018 рр. Пацієнток розподілили в основну (60 жінок) та порівняльну (30 жінок) групи залежно від методів лікування. Вік жінок коливався від 18 до 49 років (у середньому 34,52 22,51). У дослідну групу були включені пацієнтки з простою та комплексною неатиповою та атиповою гіперплазією ендометрія відповідно до класифікації гіперпроліферативних процесів ендометрія (розроблена субкомітетом по тілу матки Міжнародного товариства гінекологів-патологів і затверджена BOO3, 1994) [27].

У групу дослідження не входили медичні карти жінок з аліментарно-конституційним ожирінням (IMT > 30,0).

Контрольну групу склали 30 пацієнток-добровольців тієї ж вікової категорії, з порушеною менструальною функцією без ознак ГПЕ. За згодою пацієнток їм проводили біопсію за допомогою шприца Брауна з внутрішньою канюлею («Пайпель» (Pipelle de Cornier) біопсія) 3 дослідженням евакуйованого матеріалу з порожнини матки. Результати гістологічного дослідження підтвердили відсутність ознак ГЕ.

Наявність таких збудників, як Micoplasma hominis, Ureaplasma urealiticum, Chlamydia trachomatis, Herpex simplex virus I, II, виявляли методом імунофрерментного 
аналізу (ІФА) за стандартною методикою [8, 28]. Досліджували наявність як IgG, так і IgM. Матеріалом для дослідження була венозна кров. Gardnerella vaginalis, Trichomonas vaginalis виявили в мазках $з$ піхви та уретри за допомогою стандартної методики полімеразної ланцюгової реакції. Виявлення папіломавірусу людини (ПВЛ) 16/18 проводили за допомогою методу полімеразної ланцюгової реакції [28].

Усі діагностичні та лікувальні маніпуляції проводились після письмової згоди пацієнток на обстеження та лікування відповідно до протоколу, схваленого комітетом 3 біоетики (№53/03.06.2019). Згоду на хірургічне лікування було отримано до початку лікування.

Отримані дані обробляли стандартними статистичними методами, використовуючи персональний комп'ютер HP PREMIER EXPERIENCE з програмою Microsoft Word 2010, графріку побудовано з використанням програми Microsoft Excel. Статистичну обробку проводили програмою Statistika 10. Для статистичної обробки визначали якісні та кількісні змінні. Для якісних даних був проведений частотний аналіз виникнення ознак із визначенням помилки середнього і $95 \%$ довірчого інтервалу. Кількісні змінні перевіряли на нормальність розподілу 3 використанням описової статистики критеріїв Колмогорова-Смирнова. Для оцінки ризиків визначали ставлення шансів, довірчі інтервали, відносний ризик, етіологічну частку впливу, абсолютний (безпосередньо пов'язаний ризик), відсоток пов'язаного ризику і пов'язаний ризик популяції [29].
РЕЗУЛЬТАТИ ДОСЛІДЖЕННЯ ТА ЇХ ОБГОВОРЕНня. Частота виявлення токсоплазмової інфекції була в цілому низькою $(7-7,5)$ \% і статистично не відрізнялася між групами (табл. 1).

Частота виявлення урогенітального хламідіозу, мікоплазмозу, уреаплазмозу та токсоплазмозу статистично не відрізнялася у пацієнток обстежених груп і складала від 3,33 до 10,0 \% ( $>>0,05)$.

Крім того, не було виявлено статистично значимих відмінностей в частоті перенесених венеричних захворювань у пацієнток обстежених груп, частота перенесеної гонореї досягала 2,78 \%, бактеріального вагінозу $8,89 \%$ (табл. 2).

Розподіл пацієнток обстежених груп за частотою носійства вірусів простого герпесу (ВПГ) I і II типів був виражений: виявлено значно більшу частоту носійства ВПГ I типу в I та II групах, у пацієнток з ГПЕ - порівняно $з$ контрольною групою - здоровими пацієнтами. Частота носійства вірусу простого герпесу складала від 6,67 до 16,67 \% у всіх обстежених груп. Носійство цитомегаловірусної інфекції у пацієнток обстежених груп виявлялося з частотою від 10 до 13,33 \% (табл. 3).

Було встановлено, що частота виявлення вірусу папіломи людини 16 і 18 типів була достовірно вищою в групах із ГПЕ (I та II групи), що, очевидно, не є випадковістю, саме тому не можна виключати роль персистенції мікробного агента в порушенні репаративних властивостей ендометрія з розвитком його гіперплазії.

Таблиця 1. Урогенітальні інфекції (n=120)

\begin{tabular}{|c|c|c|c|c|c|c|}
\hline \multirow[t]{2}{*}{ Показники } & \multicolumn{2}{|c|}{$\begin{array}{c}\text { Група 1, n=60 } \\
\text { (основна група ГПЕ) }\end{array}$} & \multicolumn{2}{|c|}{$\begin{array}{c}\text { Група 2, n=30 } \\
\text { (порівняння ГПЕ) }\end{array}$} & \multicolumn{2}{|c|}{$\begin{array}{c}\text { Група 3, n=30 } \\
\text { (контрольна група) }\end{array}$} \\
\hline & абс. & $\%$ & абс. & $\%$ & абс. & $\%$ \\
\hline Хламідіоз & 5 & 8,33 & 3 & 10,00 & 3 & 10,00 \\
\hline Уреаплазмоз & 4 & 6,67 & 2 & 6,67 & 1 & 3,33 \\
\hline Мікоплазмоз & 3 & 5,00 & 2 & 6,67 & 2 & 6,67 \\
\hline Токсоплазмоз & 6 & 10,00 & 3 & 10,00 & 2 & 6,67 \\
\hline
\end{tabular}

Примітка. Статистично значимих відмінностей між групами не виявлено, p>0,05 (критерій Хі-квадрат).

Таблиця 2. Венеричні захворювання $(\mathrm{n}=120)$

\begin{tabular}{|c|c|c|c|c|c|c|}
\hline \multirow[t]{2}{*}{ Показники } & \multicolumn{2}{|c|}{$\begin{array}{c}\text { Група 1, n=60 } \\
\text { (основна група ГПЕ) }\end{array}$} & \multicolumn{2}{|c|}{$\begin{array}{c}\text { Група 2, n=30 } \\
\text { (порівняння ГПЕ) }\end{array}$} & \multicolumn{2}{|c|}{$\begin{array}{c}\text { Група 3, n=30 } \\
\text { (контрольна група) }\end{array}$} \\
\hline & абс. & $\%$ & абс. & $\%$ & абс. & $\%$ \\
\hline Бактеріальний вагіноз & 6 & 10,00 & 3 & 10,00 & 2 & 6,67 \\
\hline Трихомоніаз & 3 & 5,00 & 1 & 3,33 & - & - \\
\hline
\end{tabular}

Примітка. Статистично значимих відмінностей між групами не виявлено, р>0,05 (критерій Хі-квадрат).

Таблиця 3. Вірусні інфекції ( $\mathrm{n=120)}$

\begin{tabular}{|c|c|c|c|c|c|c|}
\hline \multirow[t]{2}{*}{ Показники } & \multicolumn{2}{|c|}{$\begin{array}{c}\text { Група 1, n=60 } \\
\text { (основна група ГПЕ) }\end{array}$} & \multicolumn{2}{|c|}{$\begin{array}{c}\text { Група 2, n=30 } \\
\text { (порівняння ГПЕ) }\end{array}$} & \multicolumn{2}{|c|}{$\begin{array}{c}\text { Група 3, n=30 } \\
\text { (контрольна група) }\end{array}$} \\
\hline & абс. & $\%$ & абс. & $\%$ & абс. & $\%$ \\
\hline Вірус простого герпесу, I тип & 10 & 16,67 & 4 & 13,33 & 4 & 13,33 \\
\hline Вірус простого герпесу, II тип & 4 & 6,67 & 2 & 6,67 & 2 & 6,67 \\
\hline Цитомегаловірус & 8 & 13,33 & 3 & 10,00 & 4 & 13,33 \\
\hline Вірус папіломи 16/18 тип & 25 & 41,67 & 12 & 40,00 & 3 & 10,00 \\
\hline
\end{tabular}

Примітка. Статистично значимих відмінностей між групами не виявлено, p>0,05 (критерій Хі-квадрат). 
ВИСНОВОК. Інфекційні агенти мають важливу роль у розвитку гіперпластичних змін слизової оболонки матки. Найбільшого розповсюдження серед інфекційних агентів набув вірус папіломи людини 16 і 18 тип, який у дослідних | та || групах був виявлений у 40,0-41,67 \% порівняно 3 контрольною III групою - 10,0 \% Вищезазначене зумовлює необхідність проведення якісного інфекційного скринінгу із формуванням груп ризику та подальшим етіопатогенетичним лікуванням.

\section{СПИСОК ЛІТЕРАТУРИ}

1. Royal Coll Royal College of Obstetricians and Gynaecologists, British Society for Gynaecological Endoscopy, Management of Endometrial Hyperplasia, Green-top Guideline No. 67, London: RCOG, 2016.

2. Бенюк В. О. Сучасні підходи до діагностики гіперпластичних процесів ендометрія у жінок репродуктивного віку / В. О. Бенюк, В. В. Курочка, В. М. Гончаренко // Проблемы, достижения и перспективы развития медико-биологических наук и практического здравоохранения. - 2009. - Т. 145 № 3. - С. 3004-3005.

3. Павловская М. А. Гиперплазия эндометрия у женщин фрертильного возраста: клиника, диагностика, патогенез и возможности терапии / М. А. Павловская // Журнал Гродненского государственного медицинского университета. -2015. - № 2. - C. 123-127.

4. Morphological features of uterine polyps in females of reproductive age / N. Y. Gorban, T. D. Zadorozhna, I. B. Vovk, I. V. Zhulkevych // Вісник наукових досліджень. - 2019. № 2. - C. 47-52.

5. Жулкевич І. В. Персоналізація в онкології: індивідуальний підхід до профрілактики тромбоемболічних ускладнень при пангістеректомії / І. В. Жулкевич, Б. Д. Кривокульський // Вісник соціальної гігієни та організації охорони здоров'я України. - 2018. - № 4 (78). - С. 11-18.

6. Бойчук А. В. Гіперплазія ендометрія - сучасний системно-патогенетичний погляд на проблему (огляд літератури) / А. В. Бойчук, В. С. Шадріна, Т. В. Верещагіна // Актуальні питання педіатрії, акушерства та гінекології. 2019. - № 1. - C. 67-72.

7. Hogg S. Endometriosis / S. Hogg, S. Vyas // Obstetrics, Gynaecology and Reproductive Medicine. - 2015. - Vol. 25 , Issue 5. - P. 133-141.

8. Use of primary high-risk human papillomavirus testing for cervical cancer screening: Interim clinical guidance / W. K. Huh, K. A. Ault, D. Chelmow [et al.] // Gynecol Oncol. -2015. Vol. 136 (2). - P. 178-182.

9. A critical assessment of the "sterile womb" and "in utero colonization" hypotheses: implications for research on the pioneer infant microbiome / M. E. Perez-Muñz, M. C. Arrieta, A. E. RamerTait, J. Walter // Microbiome. - 2017. - Vol. 5, No. 1. - Article number: 48 (2017)

10. Peymani R. Microbiome, Infection and Inflammation in Infertility / R. Peymani, A. DeCherney. In book: Genital Infections and Infertility; In Darwish A. (Ed.) Chapter 8, InTech; 2016. 99. 133. DOI: $10.5772 / 63090$

11. U.S. National Cancer Institute. Surveillance, Epidemiology, End Results (SEER) Cancer Statistics Review, 1975-2013. Access mode : https://seer.cancer.gov/csr/1975_2013/. (Last accessed January 31, 2017).

12. Подольський Вл. В. Стан мікробіоценозу урогеніталь-
ПЕРСПЕКТИВИ ПОДАЛЬШИХ ДОСЛІДЖЕНЬ. 3 огляду на значну роль інфекційних агентів у патогенезі гіперпроліферативних процесів ендометрія, вважаємо за необхідне проведення додаткових досліджень стану ендометрія та вивчення інших впливів на ендометрій для удосконалення комплексної медикаментозної терапії у хворих з ГПЕ. Перспективним видається детальна морфометрія різних гістотипів ГПЕ з імуногістохімічним дослідженням із визначенням особливості експресії рецепторів у ядрах клітин залоз і строми, а також визначення експресії маркерів проліферації (Кі-67).

них органів у жінок з порушенням репродуктивного здоров'я та змінами вегетативного гомеостазу / Вл. В. Подольський, Т. О. Лисяна, І. Г. Пономарьова // Здоровье женщины. - 2015. - № 2. - C. 142-150.

13. Peculiarities of uterine cavity biocenosis in patients with different types of endometrial hyperproliferative pathology I N. Ye. Horban, I. B. Vovk, T. O. Lysiana [et al.] // Journal of Medicine and Life. - 2019. - Vol. 12 (3). - P. 266-270.

14. Association between chronic pelvic pain symptoms and the presence of endometriosis / N. V. Apostolopoulos, K. I. Alexandraki, A. Gorry, A. Coker // Archives of Gynecology and Obstetrics. - 2016. - Vol. 293. - P. 439-445.

15. Barcellos M. B. Agreement between the preoperative findings and the operative diagnosis in patients with deep endometriosis / M. B. Barcellos, B. Lasmar, R. Lasmar // Archives of Gynecology \& Obstetrics. - 2016. - Vol. 293. P. 845-850.

16. Accuracy of Hysteroscopic Endomyometrial Biopsy in Diagnosis of Adenomyosis. Journal of Minimally Invasive Gynecology / D. M. R. Dakhly, G. A. F. Abdel Moety, W. Saber [et al.] // J. Minim. Invasive Gynecol. - 2016. - Vol. 23 (3). P. 364-371. DOI: 10.1016/j.jmig.2015.11.004.

17. Heavy menstrual bleeding (update). National Guideline Alliance (UK). London: National Institute for Health and Care Excellence (UK); 2018 Mar. (NICE Guideline, No. 88.)

18. Validation of a score to guide endometriosis therapy for the non-specialized gynecologist / R. B. Lasmar, B. P. Lasmar, R. Keller Celeste [et al.] // International Journal of Gynecology and Obstetrics. - 2015. - Vol. 131. - P. 78-81.

19. Lindsay S. F. Emerging therapy for endometriosis / S. F. Lindsay, D. E. Luciano, A. A. Luciano // Expert Opin. Emerg. Drugs. - 2015. - Vol. 20 (3). - P. 449-461. DOI: $10.1517 / 14728214.2015 .1051966$.

20. Human papillomavirus genotype-specific prevalence across the continuum of cervical neoplasia and cancer / N. E. Joste, B. M. Ronnett, W. C. Hunt [et al.] // Cancer Epidemiol Biomarkers Prev. - 2015. - Vol. 24. - P. 230-240.

21. Inefficiencies and high-value improvements in U.S. cervical cancer screening practice: a cost-effectiveness analysis / J. J. Kim, N. G. Campos, S. Sy [et al.] // Ann. Intern. Med. 2015. - Vol. 163. - P. 589-597.

22. Screening for cervical cancer with high-risk human papillomavirus testing: A systematic evidence review for the U.S. I J. Melnikow, J. T. Henderson, B. U. Burda [et al.] // Preventive services task force. Evidence synthesis No. 158. AHRQ Publication No. 17-05231-EF-1. Rockville, MD: Agency for Healthcare Research and Quality; 2017.

23. Elkhalek Abd Y. I. Comparison of 3 dimensional sonohysterography and hysteroscopy in Premenopausal women with abnormal uterine bleeding / Y. I. Abd Elkhalek, O. F. Kamel, 
H. El-Sabaa // Egyptian Journal of Radiology and Nuclear Medicine. - 2016. - Vol. 47. - P. 1117-1122.

24. Premenopausal abnormal uterine bleeding and risk of endometrial cancer / M. E. Pennant, R. Mehta, P. Moody [et al.] // BJOG. - 2017. - Vol. 124. - P. 404-411.

25. Cancer Facts and Figures 2017. - Access mode : https:// www.cancer.org/content/dam/cancer-org/research/cancer-factsand-statistics/annual-cancer-facts-and-figures/2017/cancerfacts-and-figures-2017.pdf. (Last accessed January 31, 2017).

26. NTP Research Report on the CLARITY-BPA Core Study: A Perinatal and Chronic Extended-Dose-Range Study of Bisphe- nol A in Rats [Internet]. National Toxicology Program. Research Triangle Park (NC): National Toxicology Program; 2018 Sep.

27. WHO Classification of Tumours of Female Reproductive Organs. 4th ed. / R. J. Kurman, M. L. Carcangiu, C. S. Herrington, R. H. Young editors // Lyon: IARC, 2014.

28. Меньшиков В. Н. Микробиологические и вирусологические методы исследования / В. Н. Меньшиков. - М. : Медицина, 2015. - 278 с.

29. Мінцер О. П. Статистичні методи дослідження при виконанні дисертаційних робіт / О. П. Мінцер // Практична медицина. - 2016. - № (2). - Р. 35-42.

\section{REFERENCES}

1. Royal Coll. (2016). Royal College of Obstetricians and Gynaecologists. British Society for Gynaecological Endoscopy, Management of Endometrial Hyperplasia. Green-top Guideline No. 67, London: RCOG.

2. Beniuk, V.O., Kurochka, V.V., \& Honcharenko, V.M. (2009). Suchasni pidkhody do diahnostyky hiperplastychnykh protsesiv endometriia u zhinok reproduktyvnoho viku [Modern approaches to the diagnosis of hyperplastic processes of the endometrium in women of reproductive age]. Problemy, dostyzheniya i perspektivy razvitiya mediko-biologicheskykh nauk i prakticheskogo zdravookhraneniya - Problems, Achievements and Prospects for the Development of Medical and Biological Sciences and Practical Health Care, 145, 3 , 3004-3005 [in Ukrainian].

3. Pavlovskaya, M.A. (2015). Giperplaziya endometriya u zhenshchin fertilnogo vozrasta: klinika, diagnostika, patogenez i vozmozhosti terapii [Endometrial hyperplasia in women of childbearing age: Clinic, diagnosis, pathogenesis and treatment options]. Zhurnal Grodnenskogo gosudarstvennogo meditsinskogo universiteta - Journal of Grodno State Medical University, 2, 123-127 [in Russian].

4. Gorban, N.Y., Zadorozhna, T.D., Vovk, I.B., \& Zhulkevych, I.V. (2019). Morphological features of uterine polyps in females of reproductive age. Visnyk naukovykh doslidzhen - Bulletin of Scientific Research, 2, 47-52.

5. Zhulkevych, I.V., \& Kryvokulsky, B.D. (2018). Personalizatsiia $v$ onkolohii: indyvidualnyi pidkhid do profilaktyky tromboembolichnykh uskladnen pry panhisterektomii [Personalization in oncology: individual approach to the prevention of thromboembolic complications during hysterectomy]. Visnyk sotsialnoi hihiieny ta orhanizatsii okhorony zdorovia Ukrainy - Bulletin of Social Hygiene and Health Care Organization of Ukraine, 4 (78), 11-18 [in Ukrainian].

6. Boychuk, A.V., Shadrina, V.S., \& Vereshchahina, T.V. (2019). Hiperplaziia endometriia - suchasnyi systemno-patohenetychnyi pohliad na problemu (ohliad literatury) [Hyperplasia of the endometrium - a modern systemic and pathogenetic view of the problem (review of the literature)]. Aktualni pytannia pediatrii, akusherstva ta hinekolohii - Actual Problems of Pediatrics, Obstetrics and Gynecology, 1, 67-72 [in Ukrainian].

7. Hogg, S., \& Vyas, S. (2015). Endometriosis. Obstetrics, Gynaecology and Reproductive Medicine, 25, 5, 133-141.

8. Huh, W.K., Ault, K.A., Chelmow, D., Davey, D.D., Goulart, R.A., Garcia. F.A.R., ..., \& Einstein, M.H. (2015). Use of primary high-risk human papillomavirus testing for cervical cancer screening: Interim clinical guidance. Gynecol. Oncol., 136 (2), 178-182.

9. Perez-Muñz, M.E., Arrieta, M.C., Ramer-Tait, A.E., \& Walter, J. (2017). A critical assessment of the "sterile womb" and "in utero colonization" hypotheses: implications for research on the pioneer infant microbiome. Microbiome, 5, 1, 48 (2017).
10. Peymani, R., \& DeCherney, A. (2016). Microbiome, Infection and Inflammation in Infertility. In book: Genital Infections and Infertility. Darwish, A. (Ed.) Chapter 8, InTech, 2016.99.133. DOI: $10.5772 / 63090$.

11. U.S. National Cancer Institute. Surveillance, Epidemiology, End Results (SEER) Cancer Statistics Review, 1975-2013. Retrieved from: https://seer.cancer.gov/csr/1975_2013/. (Last accessed January 31, 2017).

12. Podolskyi, VI.V., Lysyana, T.O., \& Ponomarova, I.H. (2015). Stan mikrobiotsenozu urohenitalnykh orhaniv u zhinok z porushenniam reproduktyvnoho zdorovia ta zminamy vehetatyvnoho homeostazu [The state of microbiocenosis of urogenital organs in women with reproductive health disorders and changes in autonomic homeostasis]. Zdorove zhenshchyny - Women's Health, 2, 142-150 [in Ukrainian].

13. Horban, N.Ye., Vovk, I.B., Lysiana, T.O., Ponomariova, I.H., \& Zhulkevych, I.V. (2019). Peculiarities of uterine cavity biocenosis in patients with different types of endometrial hyperproliferative pathology. Journal of Medicine and Life, 12 (3), 266-270.

14. Apostolopoulos, N.V., Alexandraki, K.I., Gorry, A., \& Coker, A. (2016). Association between chronic pelvic pain symptoms and the presence of endometriosis. Archives of Gynecology and Obstetrics, 293, 439-445.

15. Barcellos, M.B., Lasmar, B., \& Lasmar, R. (2016). Agreement between the preoperative findings and the operative diagnosis in patients with deep endometriosis. Archives of Gynecology \& Obstetrics, 293, 845-850.

16. Dakhly, D.M.R., Abdel Moety, G.A.F., Saber, W., Gad Allah, S.H., Hashem, A.T., \& Abdel Salam, L.O.E. (2016). Accuracy of hysteroscopic endomyometrial biopsy in diagnosis of adenomyosis. J. Minim. Invasive Gynecol, 23 (3), 364-371. DOI: 10.1016/j.jmig.2015.11.004.

17. Heavy menstrual bleeding (update). National Guideline Alliance (UK). London: National Institute for Health and Care Excellence (UK); 2018 Mar. (NICE Guideline, No. 88.)

18. Lasmar, R.B., Lasmar, B.P., Celeste, R.K., Larbig, A., \& De Wilde, R.L. (2015). Validation of a score to guide endometriosis therapy for the non-specialized gynecologist. International Journal of Gynecology and Obstetrics, 131, 78-81.

19. Lindsay, S.F., Luciano, D.E., \& Luciano, A.A. (2015). Emerging therapy for endometriosis. Expert Opin Emerg Drugs, 20 (3), 449-461. DOI: 10.1517/14728214.2015.1051966.

20. Joste, N.E., Ronnett, B.M., Hunt, W.C., Pearse, A., Langsfeld, E., Leete, T., ..., \& Wheeler, C.M. (2015). Human papillomavirus genotype-specific prevalence across the continuum of cervical neoplasia and cancer. Cancer Epidemiol. Biomarkers Prev., 24, 230-240.

21. Kim, J.J., Campos, N.G., Sy, S., Burger, E.A., Cuzick, J., Castle, P.E., ..., \& Wheeler, C.M. (2015). Inefficiencies and high-value improvements in U.S. cervical cancer screening 
practice: a cost-effectiveness analysis. Ann. Intern. Med., 163, 589-597.

22. Melnikow, J., Henderson, J.T., Burda, B.U., Senger, C.A., Durbin, S., \& Soulsby, M.A. (2017). Screening for cervical cancer with high-risk human papillomavirus testing: A systematic evidence review for the U.S. Preventive services task force. Evidence synthesis No. 158. AHRQ Publication No. 17-05231EF-1. Rockville, MD: Agency for Healthcare Research and Quality; 2017.

23. Elkhalek, Abd Y.I., Kamel, O.F., \& El-Sabaa, H. (2016). Comparison of 3 dimensional sonohysterography and hysteroscopy in Premenopausal women with abnormal uterine bleeding. Egyptian Journal of Radiology and Nuclear Medicine, 47, 1117-1122.

24. Pennant, M.E., Mehta, R., Moody, P., Hackett, G., Prentice, A., Sharp, S.J., \& Lakshman, R. (2017). Premenopausal abnormal uterine bleeding and risk of endometrial cancer. BJOG, $124,404-411$.
25. Cancer Facts and Figures 2017. Retrieved from: https:// www.cancer.org/content/dam/cancer-org/research/cancer-factsand-statistics/annual-cancer-facts-and-figures/2017/cancerfacts-and-figures-2017.pdf. (Last accessed January 31, 2017).

26. NTP Research Report on the CLARITY-BPA Core Study: A Perinatal and Chronic Extended-Dose-Range Study of Bisphenol $A$ in Rats. National Toxicology Program. Research Triangle Park (NC): National Toxicology Program; 2018.

27. Kurman, R.J., Carcangiu, M.L., Herrington, C.S., \& Young, R.H. (Eds.). WHO Classification of Tumours of Female Reproductive Organs. 4th ed. Lyon: IARC, 2014.

28. Menshikov, V.N. (2015). Mikrobiologicheskiye i virusologicheskiye metody issledovaniya [Microbiological and virological research methods]. Moscow: Meditsina [in Russian].

29. Mintser, O.P. (2016). Statystychni metody doslidzhennia pry vykonanni dysertatsiinykh robit [Statistical methods of tracking in the performance of dissertations]. Praktychna medytsyna - Practical Medicine, (2), 35-42 [in Ukrainian].

Отримано 06.05.20

Прийнято до друку 09.06.20

Електронна адреса для листування: vereshchagina_tv@tdmu.edu.ua 